\title{
SUBSIDENCE OF PUNA, HAWAII INFERRED FROM SULFUR CONTENT OF DRILLED LAVA FLOWS
}

\author{
JAMES G. MOORE ${ }^{1}$ and DONALD M. THOMAS ${ }^{2}$ \\ ${ }^{1}$ U.S. Geological Survey, Menlo Park, CA 94025, U.S.A. \\ ${ }^{2}$ Hawaii Institute of Geophysics, Hgnolulu, HI 96822, U.S.A.
}

(Received December 4, 1987; accepted for publication January 14, 1988)

\begin{abstract}
Moore, J.G. and Thomas, D.M., 1988. Subsidence of Puna, Hawaii inferred from sulfur content of drilled lava flows. J. Volcanol. Geotherm. Res., 35: 165-171.

Sulfur was analyzed in more than 200 lava samples from five drill holes located on the east rift zone of Kilauea volcano on the island of Hawaii. The sulfur content is a gage of whether lava was erupted subaerially (low sulfur) or erupted subaqueously (high sulfur). Despite considerable variation, sulfur is generally low (less than $0.025 \%$ ) in the upper part of the holes, begins to increase at a depth of $250-320 \mathrm{~m}$ below sea level, and generally reaches a high level (greater than $0.1 \%$ ) indicative of steady submarine eruption at $330-450 \mathrm{~m}$ below sea level. Assuming that the island is subsiding at $2.4 \mathrm{~mm} / \mathrm{yr}$, an analysis of these data indicates that part of the variation in sulfur concentration results from past eustatic oscillation of sea level, and that the volcano (at the drill hole site) finally emerged for the last time about $98 \mathrm{ka}$. The long-term average rate of lava accumulation is roughly $4.4 \mathrm{~mm} / \mathrm{yr}$, and upward growth of the volcano at the drill hole area is about $2 \mathrm{~mm} / \mathrm{yr}$ in excess of subsidence.
\end{abstract}

\section{Introduction}

Five drill holes on the lower east rift zone of Kilauea volcano on the island of Hawaii (Fig. 1) provide a unique set of samples from the uppermost several hundred meters of lava on this part of the volcano. The holes were drilled as part of the exploration of the Puna geothermal field and extend to depths of more than $500 \mathrm{~m}$ below sea level. The drill holes penetrate lava that extends through the transition zone marking sea level at the time when the lavas at that level were erupted from the adjacent rift zone. Sulfur dissolved in molten basalt is systematically degassed and lost to the atmosphere, owing to reduction of confining pressure when lava is erupted above sea level, and is progressively retained as lava is erupted at greater depths in the sea. Therefore, it is possible to examine the nature and depth of this transition zone by examining the sulfur content of lava recovered from the drill holes.

The HGP-A well, drilled in the east rift zone of Kilauea volcano in early 1976, bottomed at $1967 \mathrm{~m}$ below the ground surface (Stone and Fan, 1978). Ten short cores were taken during the course of the drilling and 780 cutting samples were recovered at $1.5-$ to $3-\mathrm{m}$ intervals to the bottom of the hole. The lithology of the HGP-A well is better known than that of the other 4 drill holes from which cuttings have been studied (Table 1) because of the availability of

0377-0273/88/\$03.50 ㅇ 1988 Elsevier Science Publishers B.V. 
TABLE 1

Sampled Puna geothermal wells

\begin{tabular}{lllll}
\hline $\begin{array}{l}\text { Locality } \\
\text { No. }\end{array}$ & $\begin{array}{l}\text { Well } \\
\text { No. }\end{array}$ & Name & $\begin{array}{l}\text { Depth } \\
(\mathbf{m})\end{array}$ & $\begin{array}{l}\text { Collar elev. } \\
(\mathbf{m})\end{array}$ \\
\hline 1 & $2685-01$ & Ashida 1 & 2530 & 250 \\
2 & $2883-02$ & Kapoho State 1 & 2222 & 188 \\
3 & $2883-01$ & HGP.A & 1967 & 188 \\
4 & $2883-04$ & Lanipuna 1 & 2557 & 188 \\
5 & $2883-05$ & Lanipuna 6 & - & 171 \\
\hline
\end{tabular}

the cores as well as detailed drilling logs.

Macdonald (1976) estimated that the subaerial-submarine lava transition occurs between core 2 (129-132 m below sea level) which consists of dark gray dense basalt with a few pahoehoe-type vesicles, and the lower part of core $3(237-240 \mathrm{~m}$ below sea level) which is partly glassy and appears to be subaqueous pillow lava. Hence, he estimated the transition zone at 132$240 \mathrm{~m}$ below sea level. On the other hand, D.B. Palmiter, geologist in charge at the site during the drilling program, estimated that the transition zone occurred at 269-379 m below sea level based on marked reduction of red, ironoxide-stained basalt at $269 \mathrm{~m}$, bottom of red stained basalt at $330 \mathrm{~m}$, first appearance of pillow-like glass at $342 \mathrm{~m}$, and beginning of abundant glass at $379 \mathrm{~m}$ (Daniel B. Palmiter, written commun., 1976).

Clearly, the criteria for determining the hole depth at the submarine-subaerial transition are not well established and suggest a broad and complex transition zone. This study was undertaken to further examine the nature of the transition zone and to determine the utility of sulfur analyses of the drilled lava in establishing the present depth of the transition.

\section{Sulfur content of drill cuttings}

The sulfur content of basalt provides a basis for estimating the position of a volcanic vent relative to sea level. The volatiles in lava erupted under water do not escape as readily from the melt by vesiculation because of the increased hydrostatic pressure when compared with lava erupted on land. Fresh lava erupted on the axis of the Reykjanes Ridge south of Iceland below a depth of $200 \mathrm{~m}$ contains an average of $843 \mathrm{ppm}$ sulfur (Moore and Schilling, 1973). Between $200 \mathrm{~m}$ and the shallowest sample at $43 \mathrm{~m}$ depth sulfur ranges from 425 to $640 \mathrm{ppm}$. Surfaceerupted lava averages about $250 \mathrm{ppm}$.

Mauna Loa lava erupted below sea level during 1877 at $122-133 \mathrm{~m}$ depth contains $400-440$ ppm sulfur, whereas lava from the same eruption that erupted at $690 \mathrm{~m}$ depth contains 1000 ppm and lava erupted at $1000 \mathrm{~m}$ depth contains $1200 \mathrm{ppm}$ sulfur. Subaerially erupted lava contains about 160 ppm sulfur (Moore et al., 1985). Hence, available data indicate that lava erupted above sea level contains up to about $250 \mathrm{ppm}$ sulfur; sulfur is progressively retained as eruption takes place at greater depths in the sea. Hawaiian lava contains more than $400 \mathrm{ppm}$ at $122 \mathrm{~m}$ depth, and $1200 \mathrm{ppm}$ at $1000 \mathrm{~m}$ depth.

The sulfur content was determined in 215 samples of drill cuttings collected from five drill holes (Fig. 1, Table 1) down to depths of about $500 \mathrm{~m}$ below sea level. From the drill cuttings, each of which was generally collected over a depth interval of less than a few meters, about 10 fresh-appearing chips (1-3 mm in size) were hand-picked, cleaned in an ultrasonic water bath, dried, and finely pulverized. $\mathrm{A} \mathrm{V}_{2} \mathrm{O}_{5}$ flux was mixed with $250 \mathrm{mg}$ of the powdered sample which was placed in a ceramic boat, and introduced into a Leco sulfur analyzer*. The sample was fused in an oxygen atmosphere up to $1370^{\circ} \mathrm{C}$ and the combustion products analyzed by an infrared detector. The rated detection limit and precision of the instrument is $0.01 \%$ sulfur, but analysis of sulfur standards permitted determination in a relative sense to $0.005 \%$ sulfur above the detection limit.

In evaluating sulfur content of the drill cuttings several factors should be considered:

(1) Drill cuttings can stick to the side of the hole and later fall to a greater depth. However,

\footnotetext{
*Brand names are for information purposes only and do not constitute an endorsement by the U.S. Geological Survey.
} 


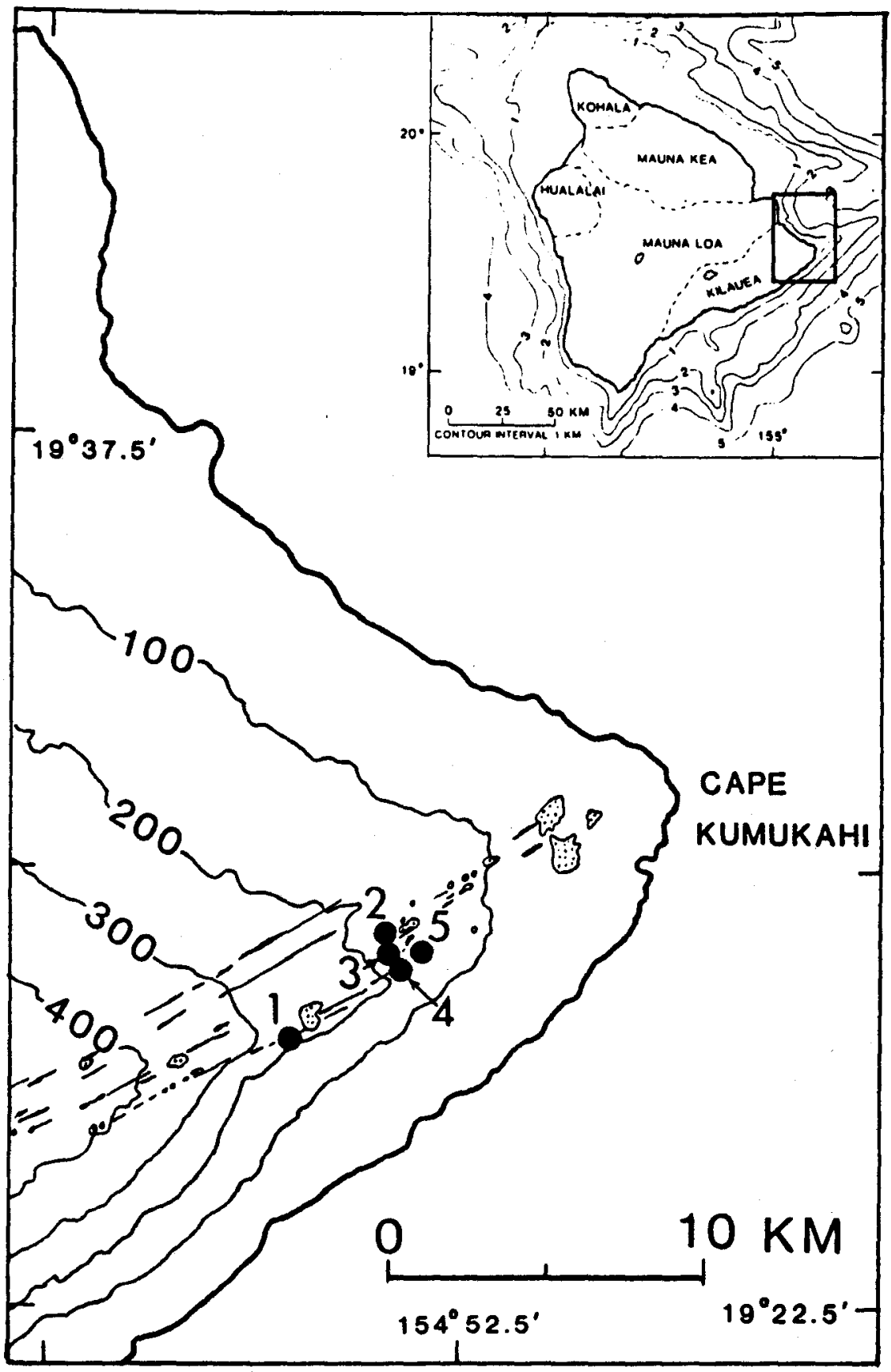

Fig. 1. Map of Puna area on the east rift zone of Kilauea volcano showing location of the 5 geothermal drill holes that were sampled (Table 1). Trend of rift zone is defined by eruptive vents (lines) and cinder cones (stippled). Elevation contours in meters.

no cuttings can be collected from a depth greater than the existing hole depth.

(2) Vents above sea level, but close to the shoreline, may contribute to the buildup of de- gassed sampled material below sea level by flow of lava across the shoreline, by explosion of clastic material into the sea, and by erosion of subaerially erupted material. However, the fact

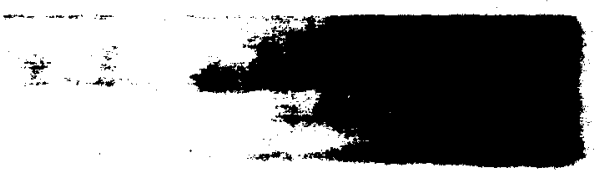




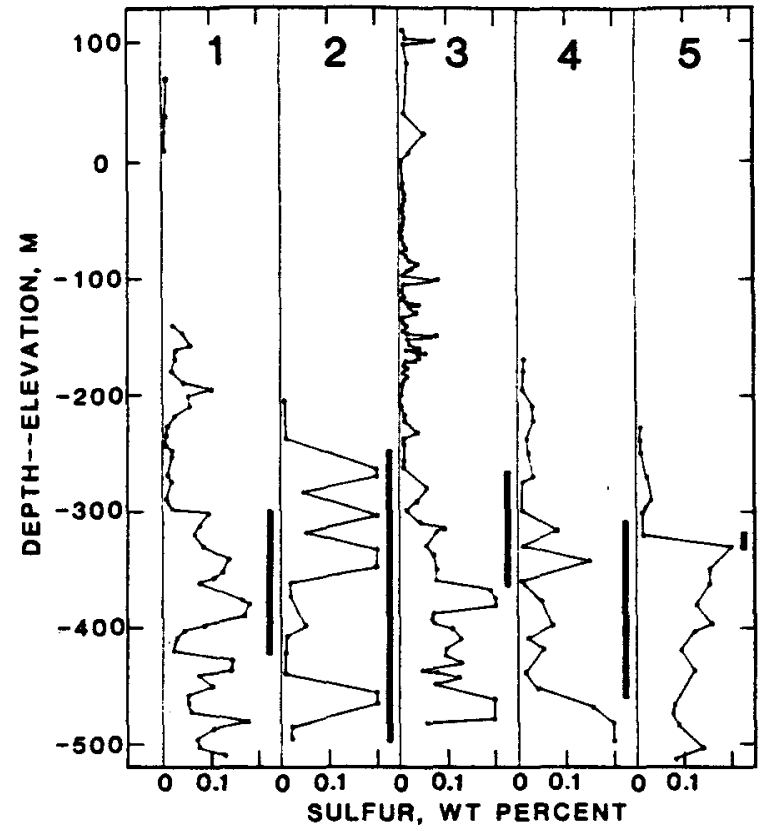

Fig. 2. Sulfur content of drill cuttings from five drill holes as located in Fig. 1 and defined in Table 1. A heavy vertical line marks the apparent subaerial-submarine lava transition zone in each drill hole. Sulfur values are truncated above $0.2 \%$.

that the drill holes are so close to the vent areas of the rift zone would place the coastline very close to the vents at the time that lavas at the drill hole site emerged above sea level.

(3) Localized faulting, slumping, and subsidence may depress subaerially erupted material below sea level.

(4) Dikes and intrusions emplaced at a high level perhaps above sea level may retain a high sulfur content because of the confining pressure of overlying older rocks.

The analysis of the drill cuttings from the five drill holes (Fig. 2) show several overall similarities. Sulfur values generally remain low (less than $0.025 \%$ ) from the present surface down to a depth of 250-320 m below sea level. Below that depth sulfur increases irregularly. The average sulfur content in the holes attains about $0.1 \%$ from 330 to $450 \mathrm{~m}$ depth below sea level. For the HGP-A hole the sulfur analyses support the transition depth of 269-379 m estimated by D. Palmiter. However, a curious feature of most of the sulfur concentration curves is their irregularity and the broad span of more than $100 \mathrm{~m}$ in which values oscillate between those typical of subaerially erupted lava and of submarineerupted lava.

Some of the spikes of high sulfur shallower than $250 \mathrm{~m}$ below sea level may result from sampled dikes and intrusions. Zones of low-sulfur lava deeper in the holes may result from downslope movement of subaerially erupted material across the shoreline. Although some deep low-sulfur values may result from fall of drill chips down the hole, this is probably a minor effect since each analysis is an average of several hand-picked chips.

\section{Rate of growth of Kilauea volcano}

The growth of Kilauea volcano above sea level by accumulation of lava flows is, of course, affected by the variations in the eustatic height of sea level. Fluctuations in eustatic sea level during the past few hundred thousand years are assumed to be similar to those estimated for the Huon peninsula, New Guinea, as based on the age of uplifted coral, and on oxygen isotope chronology from deep sea cores (Chappell and Shackleton, 1986).

The interrelation between volcano growth and shoreline processes can be examined by utilizing three assumed rates of lava buildup relative to present sea level: 1,2 , and $3 \mathrm{~mm} / \mathrm{yr}$ (Fig. 3A). These rates of lava accumulation assume that eruption is continuous rather than episodic. At the site of drill hole 3 with a buildup of $3 \mathrm{~mm} / \mathrm{yr}$ the land would have emerged above sea level $75 \mathrm{ka}$. Because of the irregularities of sea level variations, however, the situation is more complex for slower buildup rates. At 2 $\mathrm{mm} / \mathrm{yr}$, the land would have first emerged 150 $\mathrm{ka}$, then submerged $130 \mathrm{ka}$, re-emerged $112 \mathrm{ka}$, submerged $106 \mathrm{ka}$, and finally emerged for the last time $98 \mathrm{ka}$, marking a period of $52 \mathrm{ka}$ in which this part of the island was alternately 


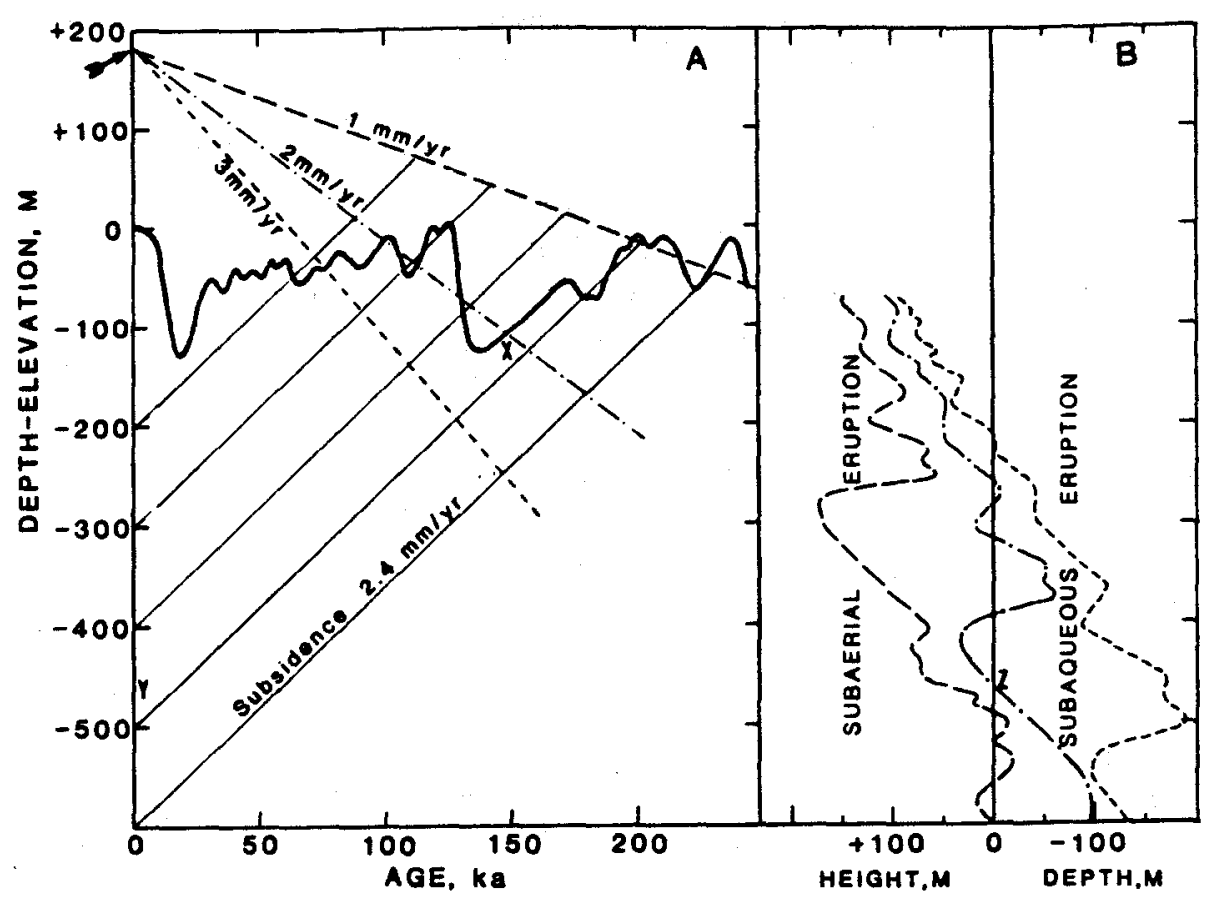

Fig. 3. Effect of sea level fluctuations, lava buildup, and island subsidence, on past ocean depth (or island elevation) at the site of Puna drill hole 3. A. Depth-time plot showing variation of sea level relative to present sea level over the last $250 \mathrm{ka}$ (heavy line, after Chappell and Shackleton, 1986), subsidence of island at $2.4 \mathrm{~mm} / \mathrm{yr}$ (parallel lines, Moore, 1987), and three rates of lava buildup at site of drill hole (arrow, elevation $188 \mathrm{~m}$ ) represented by broken lines at $1 \mathrm{~mm} / \mathrm{yr}$ (long dash), 2 $\mathrm{mm} / \mathrm{yr}$ (dash-dot), and $3 \mathrm{~mm} / \mathrm{yr}$ (short dash). B. Height above (or depth below) past sea level at top of growing lava pile at site of drill hole for three rates of lava buildup (same line designation as A). For example, on the $2 \mathrm{~mm} / \mathrm{yr}$ lava buildup trend (dash-dot line) in $\mathrm{A}, \mathrm{X}$ indicates the time ( $150 \mathrm{ka}$ ) when lava flows first breached sea level at the drill hole site. $\mathrm{Y}$ indicates the depth ( $470 \mathrm{~m}$ below present sea level) at which this lava now occurs assuming a steady subsidence of $2.4 \mathrm{~mm} /$ yr. Z (in plot B) shows the depth of this sea-level erupted lava in the drill hole in comparison with adjacent lava flows erupted either below or above sea level.

emerged and submerged (Fig. 3A). In such cases the subaerial-submarine transition may occur over a broad zone in both time and hole depth. Assuming a buildup of $1 \mathrm{~mm} / \mathrm{yr}$, the entire period of alternating emergence and submergence is not recorded by the sea level curve as shown in Fig. 3A, but the island emerged from below sea level for the last time about $200 \mathrm{ka}$ after moving back and forth through sea level for tens of thousands of years.

The present depth in the hole of these lava emergences and submergences is dependent on the rate of island subsidence. The Hilo tide gage, located $30 \mathrm{~km}$ north-northwest of the drill hole area, has recorded an average absolute subsid- ence rate of $2.4 \mathrm{~mm} / \mathrm{yr}$ for the past 38 years (Moore, 1987). A similar rate $(2.5 \mathrm{~mm} / \mathrm{yr})$ was determined for the past half million years on the basis of the age of drowned reefs off Kohala volcano on the northern part of the island (Moore and Campbell, 1987). We assume that the subsidence rate at the drill hole area is similar to that at Hilo because a compilation of seismic evidence indicates that depression of the base of the crust is similar at Hilo and the drill hole area (Moore, 1987, his fig. 2.4). However, the local subsidence rate at the drill hole site may exceed the regional rate because of the possibility of local drop of rift zone grabens, or gravitational drop of the steep south flank of 
the volcano. On the other hand, the local rate may be less than the regional rate because of the possibility of upbowing of the surface by rift zone intrusions. Effects of these processes are not evaluated in the simplified model presented here.

By graphically combining the assumptions of subsidence, sea level fluctuation, and lava buildup, we can evaluate the age and the depth or elevation of the volcano surface at the drill hole area at the time of lava accumulation (Fig. $3 \mathrm{~A}, \mathrm{~B}$ ). Using the $2.4 \mathrm{~mm} / \mathrm{yr}$ assumed rate of island subsidence, the $1 \mathrm{~mm} / \mathrm{yr}$ lava buildup would produce a final island emergence that would now be $480 \mathrm{~m}$ below sea level; the $2 \mathrm{~mm} /$ $\mathrm{yr}, 260 \mathrm{~m}$ below sea level; and the $3 \mathrm{~mm} / \mathrm{yr}, 210$ $\mathrm{m}$ below sea level.

The best fit of the curves of ocean depth (and island height) at the drill hole site at the time of eruption with the sulfur content of the drill cuttings which is a measure of ocean depth, is for the $2 \mathrm{~mm} / \mathrm{yr}$ curve of lava buildup relative to present sea level (compare Fig. 3B with Fig. 2 ). The assumed subsidence of $2.4 \mathrm{~mm} / \mathrm{yr}$ means that the estimated rate of lava accumulation on the subsiding volcanic edifice is 4.4 $\mathrm{mm} / \mathrm{yr}$. If, for example, the average lava flow thickness were $5 \mathrm{~m}$, then the rate of $4.4 \mathrm{~mm} / \mathrm{yr}$ lava addition would require a new lava flow at a given place every 1136 years and no intervening activity.

This rate of volcanic accumulation can be compared with the average magma supply rate, $0.1 \mathrm{~km}^{3} / \mathrm{yr}$ (calculated vesicle-free), at Kilauea volcano as estimated by eruptions and intrusions during the period 1952-1971 (Swanson, 1972). This estimate was made during a period of inactivity of Mauna Loa volcano and is probably a measure of magma delivered from the entire Hawaiian hot spot. If erupted as vesicular surface flows or shallow intrusions this volume would be closer to $0.15 \mathrm{~km}^{3} / \mathrm{yr}$. Such material is ultimately distributed over the surfaces and injected as intrusions over a sizable part of the southeastern end of the Hawaiian Ridge including the subaerial and submarine flanks of
Kilauea, Mauna Loa, and Loihi volcanoes.

This view is supported by the nature of the submarine slopes of the volcanoes comprising the island of Hawaii (Mark and Moore, 1987). Both Mauna Loa and Kilauea show steep submarine slopes that extend upward to present sea level indicating that the volcanoes are in the active shield-building stage and that the constant seaward growth of the shoreline by lava flows is maintaining these steep slopes. The other three volcanoes comprising the island (Mauna Kea, Hualalai, and Kohala) show much more gentle (originally subaerially constructed) slopes that have been carried downward below sea level by post-volcanic subsidence. The total area of Mauna Loa, Kilauea, and Loihi volcanoes as measured down to the base of the volcanoes at a depth of $5 \mathrm{~km}$ is about $20,000 \mathrm{~km}^{2}$. The volcanic accumulation rate of $7.5 \mathrm{~mm} / \mathrm{yr}$ calculated by distributing the $0.15 \mathrm{~km}^{3}$ of magma over $20,000 \mathrm{~km}^{2}$ is within reasonable agreement with the $4.4 \mathrm{~mm} /$ yr determined by volcanic buildup estimates at the drill hole site. Perhaps eruption rates as measured during the period 1952-1971 are somewhat higher than the long-term average.

\section{Conclusions}

Sulfur analysis of drill cuttings in 5 drill holes along the east rift zone of Kilauea volcano provides information on the nature and depth of the transition from submarine-erupted to subaerially erupted lava during the buildup of this part of the volcano. This work leads to the following conclusions:

(1) Sulfur is generally low (less than 0.025 percent), typical of subaerial eruption, from the present surface about $188 \mathrm{~m}$ above sea level down to 250-320 m below sea level. Below that depth it increases irregularly and attains a high value (greater than 0.1 percent), typical of submarine eruption, on down from $330-450 \mathrm{~m}$ below sea level.

(2) The submarine-subaerial transition zone is commonly irregular and broad. It occurs over 
$10-200 \mathrm{~m}$ in section and over a period of up to several tens of thousands of years. Part of this range results from the interaction between fluctuating past sea level, general subsidence of the island, and upward volcanic construction.

(3) The rate of lava buildup at the drill hole area for the last few hundred thousand years is roughly $2 \mathrm{~mm} / \mathrm{yr}$ relative to present sea level, and roughly $4.4 \mathrm{~mm} / \mathrm{yr}$ relative to the pre-volcanic sea floor.

\section{Acknowledgements}

Sulfur analyses were performed in the laboratories of the U.S. Geological Survey, Menlo Park, California by P. Klock and T. Fries. P.F. Fan provided valuable help in selecting and transmitting cuttings from the HGP-A well, and William Loskutoff prepared drill cutting samples for analysis. We thank D.A. Clague and M.J. Thompson for helpful reviews.

\section{References}

Chappell, J. and Shackleton, N.J., 1986. Oxygen isotopes and sea level. Nature, 324: 137-140.

Macdonald, G.A., 1976. Geothermal exploration in Hawaii. Prepared for the Fifth Session of the Committee for Coordination of Joint Prospecting for Mineral Resources in South Pacific Offshore Areas of the United Nations, Rarotonga, November, 1976,9 pp.

Mark, R.K. and Moore, J.G., 1987. Slopes of the Hawaiian Ridge. U.S. Geol. Surv., Prof. Pap., 1350: 101-107.

Moore, J.G., 1987. Subsidence of the Hawaiian Ridge, 1987. U.S. Geol. Surv., Prof. Pap., 1350: 85-100.

Moore, J.G. and Campbell, J.F., 1987. Age of tilted reefs, Hawaii. J. Geophys. Res., 92: 2641-2646.

Moore, J.G., Fornari, D.J. and Clague, D.A., 1985. Basalts from the 1877 submarine eruption of Mauna Loa, Hawaii: New data on the variation of palagonitization rate with temperature. U.S. Geol. Surv., Bull. 1663, 11 pp.

Moore, J.G. and Schilling, J.-G., 1973. Vesicles, water, and sulfur in Reykjanes Ridge basalt. Contrib. Mineral. Petrol., 41: 105-118.

Stone, C. and Fan, P.-F., 1978. Hydrothermal alteration of basalts from Hawaii geothermal project well-A, Kilauea, Hawaii. Geology, 6: 401-404.

Swanson, D.A., 1972. Magma supply rate of Kilauea volcano, 1952-1971. Science, 175: 169-170. 